$\underline{\beta-1}$

\title{
Pharmacological impact of Agaricus bisporus extract in carbon tetrachloride-induced hepatotoxicity in rats
}

\author{
Manar Rizk ${ }^{1}$, Deena El-Deberky ${ }^{1}$, Faten Elsayd ${ }^{1}$, Aziza Amin ${ }^{2}$, Abubakr El-Mahmoudy ${ }^{1}$ * \\ ${ }^{1}$ Department of Pharmacology, Faculty of Vet. Medicine, Benha University, 13736 Qalioubeya, EGYPT \\ ${ }^{2}$ Department of Pathology, Faculty of Vet. Medicine, Benha University, 13736 Qalioubeya, EGYPT \\ *Corresponding author E-mail: a.elmahmoudy@fvtm.bu.edu.eg
}

\begin{abstract}
Drug-induced hepatotoxicity is a frequent cause of liver injury worldwide. The present study was designed to evaluate the possible hepatoprotective potential Agaricus bisporus extract (ABE; a type of mushrooms) in albino rats using Carbon tetrachloride $\left(\mathrm{CCl}_{4}\right)$-model of liver injury. Forty-two albino rats were utilized in this experiment arranged randomly in seven groups, six rats each, of different treatments. Hepatic injury model was induced by administration of $\mathrm{CCl}_{4}(25 \%$ in corn oil) at a dose of $2.5 \mathrm{ml} / \mathrm{kg}$, interperitoneally, twice weekly for 8 weeks (+ve control); test group rats received $\mathrm{ABE}$ at escalating doses of 200 or $400 \mathrm{mg} / \mathrm{kg}$, orally, daily for 8 weeks with exposure to CCl ${ }_{4}$; standard group rats received Silymarin at dose of $100 \mathrm{mg} / \mathrm{kg}$, orally, daily for 8 weeks along with $\mathrm{CCl}_{4}$; further 2 groups of rats received only $\mathrm{ABE}$ at the same dose levels; while rats of -ve control group received only the vehicles of the used drugs. Blood and liver tissue samples were picked out at the end of the experimental course for different assays. Biochemical analysis revealed that ABE exhibited dosedependent hepatoprotection indicated by almost normalized biomarkers, including, enzymatic liver function parameters, namely, AST, ALT, GGT \& ALP with potential \% of 93.1, 58.2, 65.2, 68.9, respectively, after ABE large dose when standardized by Silymarin; nonenzymatic parameters, namely, total protein, albumin, globulins, total bilirubin, conjugated bilirubin, unconjugated bilirubin, TAGs, Cholesterol, HDL, LDL \& VLDL with potential \% of 59.3, 54.5, 57.3, 81.8, 81.0, 80.0, 75.5, 90.4, 80.8, 84.5 \& 78.7, respectively, after ABE large dose when standardized by Silymarin. The mechanism of the obtained hepatoprotection of ABE may be based on impeding the oxidative stress mediated by the used hepatotoxin, indicated by reduced MDA (37.9\% of Silymarin), and restored SOD, Catalase \& GPx in liver homogenate with potentials of $94.9,63.0 \& 88.4 \%$ of Silymarin, respectively. Pathological findings, both macroscopic and microscopic, were supportive to the biochemical findings, where the pathological lesions caused by $\mathrm{CCl}_{4}$ as fatty degeneration of hepatocytes with vacuolated cytoplasm, proliferated fibrous connective tissue with eosinophilic edematous fluid cells plus focal and diffuse necrotic areas and hyperplastic biliary epithelium, were ameliorated dose-dependently when ABE was administered together with $\mathrm{CCl}_{4}$. Data of the present study may suggest ABE as a good natural source for promising hepatoprotective and antioxidative remedies.
\end{abstract}

Keywords: Agaricus bisporus; Mushroom; Liver Injury; $\mathrm{CCl}_{4}$; Antioxidant; Phytomedicine.

\section{Introduction}

The Liver is vital organ and plays important role in drug metabolism. Using a lot of drugs increases risk of liver injury. Drug-induced hepatotoxicity is a frequent cause of liver injury in Egypt and developed countries who are suffering from various complications in the liver (Omar et al. 2013). Population-based studies that accurately estimate the incidence and full spectrum of drug-induced liver injury are limited. However, using a prospective, population-based French study with an annual estimated incidence of $13.9 \pm 2.4$ drug induced liver injury (DILI) cases per 100,000 inhabitants, it has been extrapolated that nearly 44,000 individuals in the United States will suffer from DILI each year (Bell \& Chalasani 2009). The mechanisms of DILI indicate that mitochondria are critical targets for drug toxicity, either directly or indirectly through the formation of reactive metabolites which leads to structural alterations of proteins and mitochondrial DNA, apoptosis and necrotic cell death (Russmann et al. 2009).

If the drug injury caused by using drug(s) for a short term for treatment of acute disease conditions, it could be reversed upon cessation of $\operatorname{dug}(\mathrm{s})$. However, DILI is not avoidable along using of drugs in controlling chronic diseases where drug administration continuation is a must, such as analgesic anti-inflammatories, anti-infective agents and anticonvulsants (Hong 2019). So, in chronic cases we need to use supportive agents for liver to decrease risk of hepatic injury specially those derived from natural sources which is not a further load on the liver such as fishes, vegetables, fruits and medicinal plants (Koumbi 2017).

Among medicinal plants, mushroom (Agaricus), which is used in traditional medicine to maintain a state of good health, necessary to reduce the risk of many diseases. Modern pharmacological studies confirmed scientific evidence for such traditional applications of mushrooms including, anti-fungal (Wang \& Ng 2006), antibacterial (Karaman et al. 2009), anticancer (Khan et al. 2010) and antiviral properties (Teplyakova et al. 2012).

However, the effects of mushroom, namely Agaricus bisporus species that is growing in Egypt, as a liver supportive agent has not been studied yet. Therefore, the aim of the present study was to evaluate the hepatoprotective properties of mushroom extract (Agaricus bisporus extract, $\mathrm{ABE}$ ) in context of its antioxidant properties. To achieve this aim, the following objectives have been investigated: liver enzymatic 
markers in plasma as AST, ALT, GGT, ALP; liver non-enzymatic parameters in plasma as proteins, bilirubins, triglycerides, cholesterol and lipoproteins; oxidative stress markers in liver homogenate as MDA, superoxide dismutase, catalase and glutathione peroxidase; pathological examination of the liver both macroscopic and microscopic.

\section{Materials and methods}

\subsection{Plant part and its identification}

Agaricus bisporus is a mushroom belongs to Phylum: Basidiomycota; Class: Agaricomycetes; Order: Agaricales; Family: Agaricaceae; Genus Agaricus; Species: Agaricus bisporus (Bas \& Marks 1991). Agaricus bisporus is a young fungus either light-yellow or light-brown in color with an abutted cap, known as common mushroom, white mushroom or button mushroom (Bhushan \& Kulshreshtha 2018). The plant was identified by Dr. Gamal Ashour, Assistant Professor of Plant pathology Department, Faculty of Agriculture, Benha university, Egypt; voucher number 2383. The mushroom was obtained from the Golden mushroom group, Benha, Qalioubeya, Egypt. The mushroom was obtained in December 2019 (Fig. 1).
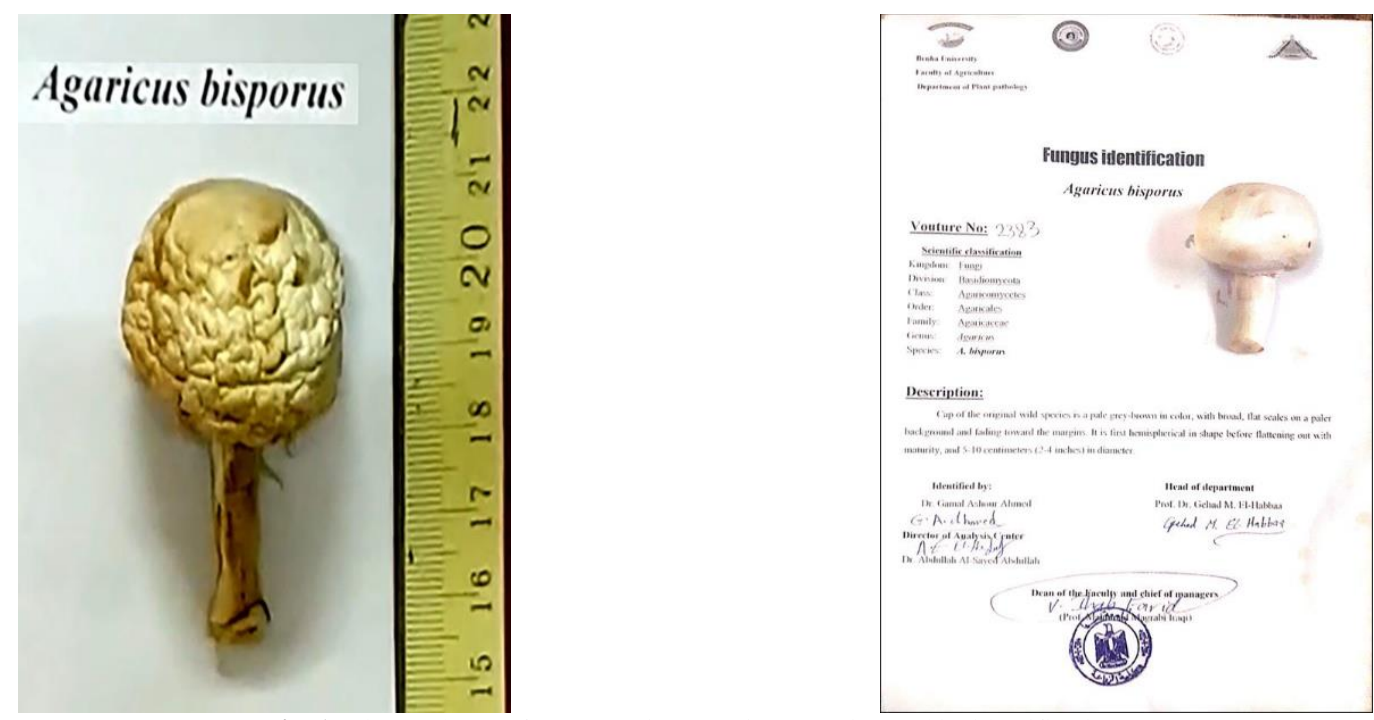

Fig. 1: The used part of Agaricus bisporus in extraction and its identification.

\subsection{Preparation of plant extract}

The buttons of Agaricus were washed by running tap water then dried in shadow at room temperature and sliced to small slices. Extraction was done by maceration viz. soaking known amount of the sliced mushroom $(1 \mathrm{~kg})$ in a known volume of 70:30 v/v hydro-ethanol (6 liters consisted of $4200 \mathrm{ml}$ distilled water $+1800 \mathrm{ml}$ ethyl alcohol). Soaking continued for 72 hours in refrigerator with shaking every 4-6 hours The extract was strained with muslin mesh and then filtered by Whatman paper \#1. The filtrate was concentrated on a shaking water bath at $70^{\circ} \mathrm{C}$ till semisolid extract was obtained and weighed ( $245 \mathrm{~g}$ were obtained). It was stored in dark tight air bottle in refrigerator.

The concentrated extract was re-constituted by dissolving $8 \mathrm{~g}$ in $200 \mathrm{ml}$ of isosaline $(0.9 \%)$ for high dose extract and dissolving $4 \mathrm{~g}$ in 200 $\mathrm{ml}$ of isosaline $(0.9 \%)$ for low dose extract. The extract was stored in dark tight air bottle in refrigerator. The concentrations of the prepared extracts were $40 \mathrm{mg} / \mathrm{ml}$ and $20 \mathrm{mg} / \mathrm{ml}$ which were used for assessment of the hepatoprotective effect of Agaricus at high dose (400 mg / $\mathrm{kg}$ ) and small dose (200 mg / kg), respectively, in rats (Harborn 1973, Ruthes et al. 2015). Percentage of yield was determined using the formula:

Yield $\%=($ weight of extract $) /($ weight of plant material $) \times 100$

\subsection{Chemicals, reagents and Kits}

Carbon tetrachloride: $\mathrm{CCl}_{4}$ was used to induce hepatic injury as a common model for hepatoprotective drug development. $\mathrm{CCl}_{4} \mathrm{was}$ obtained as 99.8\% pure liquid from Satya Sai chemicals, Andhra Pradesh, India. The chemical is formulated as bottles of one liter. $\mathrm{CCl}_{4} \mathrm{was}$ diluted in oil corn $(1: 4 \mathrm{v} / \mathrm{v})$. It was used at dose of $2.5 \mathrm{ml}$ of $25 \% \mathrm{CCl}_{4}$ in corn oil $/ \mathrm{kg}$ intraperitoneally; where a rat weighing $200 \mathrm{~g}$ receives $0.5 \mathrm{ml}$ using syringe with 22-gauge needle (Singhal \& Gupta 2012).

Silymarin: It is the main ingredient is milk thistle extract and considered as one of the most powerful currently known antioxidants and hepatoprotective agent. silymarin was obtained as Hepaticum ${ }^{\circledR}$, Produced by MUP, Ismailia, Egypt. It is formulated as suspension of 50 $\mathrm{mg} / 5 \mathrm{ml}$. Silymarin was used as such without dilution, where a rat weighing $200 \mathrm{~g}$ received $2 \mathrm{ml}$ of a Hepaticum ${ }^{\circledR}$ suspension, equivalent to100 $\mathrm{mg} / \mathrm{kg}$ (Kshirsagar et al. 2009).

Kits: The kits for estimating AST, ALT, GGT, ALP, total protein, albumin, total bilirubin and conjugated bilirubin in plasma, were supplied from Centronic GmbH Company, Am Kleinfeld, Wartenberg, Germany. The kits for estimating triglycerides, cholesterol, HDL and LDL in plasma, as well as kits of estimating oxidative stress markers, Malondialdehyde (MDA), Glutathione peroxidase (GPx), superoxide dismutase (SOD) and Catalase (CAT) in liver tissue homogenate were purchased from BioDiagnostic Company, Dokki, Giza, Egypt.

\subsection{Experimental animals}

Albino rats were used in this experiment to study the effect of $\mathrm{ABE}$ on liver injury induced by $\mathrm{CCl}_{4}$. Forty-two male rats aging 6 weeks and of average body weight $150-220 \mathrm{~g}$ were obtained from the animal house, Faculty of Veterinary Medicine, Benha University, Egypt. 
Rats were housed in wire cages at room temperature and kept under normal healthy conditions. Rats were kept in laboratory for 14 days for adaptation before the beginning of the experiment. Rats were provided with standard dietary supplements were required for growth, including, $18 \%$ protein, $4 \%$ fiber, $4 \%$ lipid, $3 \%$ minerals and vitamins (Krinke 2000); water was provided ad libitum.

\subsection{Experimental design}

A parallel experimental study design was done according to the international accepted principles for laboratory animal use.

\subsubsection{Grouping}

The acclimatized 42 rats were randomly divided into 7 groups in a parallel study design as follows:

Group (1): Negative control group: Six rats have taken $2 \mathrm{ml}$ saline, orally, once daily; and $0.5 \mathrm{ml}$ of corn oil intraperitoneally, twice weekly, for 8 weeks.

Group (2): Positive control group: Six rats have taken carbon tetrachloride $\left(\mathrm{CCl}_{4} 25 \%\right)$ at a dosage of $2.5 \mathrm{ml} / \mathrm{kg}$, intraperitoneally, twice weekly for 8 weeks to induce liver injury.

Group (3): Standard group: Six rats have taken $2 \mathrm{ml}$ Silymarin (Hepaticum)® at a dosage of $100 \mathrm{mg} / \mathrm{kg}$ through oral gavage once daily for 8 weeks as hepatoprotective agent; and $\mathrm{CCl}_{4}$ via intraperitoneal route as mentioned for group (2).

Group (4): Intoxicated, ABE small dose-treated group: Six rats received $2 \mathrm{ml}$ of low dose of Agaricus extract (200 mg/kg), orally, once daily for 8 weeks as possible hepatoprotective agent; and $\mathrm{CCl}_{4}$ via intraperitoneal route as mentioned for group (2).

Group (5): Intoxicated, ABE high dose-treated group: Six rats received $2 \mathrm{ml}$ of high dose of Agaricus extract (400 mg/kg), orally, once daily for 8 weeks as possible hepatoprotective agent; and $\mathrm{CCl}_{4}$ via intraperitoneal route as mentioned for group (2).

Group (6): Normal, ABE small dose-treated group: Six rats have taken $2 \mathrm{ml}$ of low dose of Agaricus extract (200 mg/kg), orally, once daily, for 8 weeks.

Group (7): Normal, ABE high dose-treated group: Six rats have taken $2 \mathrm{ml}$ of high dose of Agaricus extract (400 mg/kg), orally, once daily, for 8 weeks.

\subsubsection{Sampling}

Blood samples: At the end of 8-week different treatments, blood samples were collected into test tubes containing lithium heparin as anticoagulant at room temperature, then centrifuged at $900 \mathrm{Xg}$ for 5 minutes to collect plasma for biochemical analysis. These plasma samples were kept frozen at $-50{ }^{\circ} \mathrm{C}$ till used for determination of total protein, albumin, total bilirubin, conjugated bilirubin, aspartate aminotransferase, alanine aminotransferase, alkaline phosphatase, gamma glutamyl transferase, triglycerides, cholesterol, LDL and HDL. Tissue samples: Some liver specimens were collected for determination of oxidative stress markers (MDA, catalase, SOD, GPx) and some other specimens for histopathological examination. Liver tissue specimens collected for oxidative stress assessments were homogenized according to (Del Maestro \& McDonald 1985). Briefly, weighed specimens were rapidly removed and washed in ice cooled saline, dried and weighed. Then it was homogenized by electric homogenizer and centrifuged (1200Xg) in cooling centrifuge for excluding debris from the homogenate. The clear homogenate supernatants were kept frozen at $-50{ }^{\circ} \mathrm{C}$ till analysis. While liver specimens taken for histopathology examination were washed and placed in closed cups containing formalin $(10 \%)$ solution for fixation till analysis.

\subsection{Assessments}

All biochemical assessments were conducted spectrophotometrically using the above-mentioned parameter-specific kits and measuring absorbances at specific wavelengths, following the instructions of the manufacturer with minor modifications. Enzymatic activities of AST, ALT, GGT and ALP in plasma were determined according to principles described by Reitman \& Frankel (1957), Reitman \& Frankel (1957), Sacchetti et al. (1988) and Belfield \& Goldberg (1971), respectively.

Total protein and albumin were according to Gornall (1949) and Doumas et al. (1971), respectively; while total globulins fraction was calculated mathematically by subtracting the value of plasma albumin from the value of total protein (Busher 1990). Total and conjugated bilirubins were measured according to Walter \& Gerade (1970), while unconjugated one was calculated mathematically by subtraction (Walter \& Gerade 1970). TAGs, Cholesterol, HDL and LDL determination was based on the principles of Fassati \& Prencipe (1982), Richmond (1973), Lopes-Virella et al. (1977), Wieland \& Seidel (1983), respectively; VLDL concentration was calculated by dividing the triglyceride value by 5 to be the value in $\mathrm{mg} / \mathrm{dL}$ according to Wilson et al. (1981) and as cited by El-Mahmoudy et al. (2014).

Oxidation markers in liver homogenate were also determined spectrophotometrically using specific kits according to Ohkawa et al. (1979) and as cited by Gheith \& El-Mahmoudy (2018) (MDA), Nishikimi et al. (1972) (SOD), Aebi (1984) (Catalase) and Paglia \& Valentine (1967) (GPx), following the instructions of the manufacturer. Liver histopathological examination was done according to the technique described by Bancroft \& Gamble (2008).

\subsection{Statistical analysis}

All data are represented as mean \pm SE of 6 observations. One-way analysis of variance (ANOVA) followed by Tukey's post-hoc tests were done using GraphPad Prism v. 6 software to determine the significant differences among groups. Values were considered significant at $P$ value $\leq 0.05$.

\section{Results}

\subsection{Liver function parameters}

Results of the effects of ABE on enzymatic liver parameters are presented in Table 1; while its effects on liver non-enzymatic parameters as proteins, bilirubins, lipids and lipoproteins are presented in Tables $2,3 \& 4$, respectively. 
Table 1: The effect of Agaricus bisporus extract (ABE, 200 and $400 \mathrm{mg} / \mathrm{Kg}$, po, daily) and Silymarin (100 mg/Kg, po, daily) on activities of liver enzymes in plasma of normal and $\mathrm{CCl}_{4}$-intoxicated rats $(2.5 \mathrm{ml} / \mathrm{Kg}, 25 \%$, twice weekly) after 8 weeks of different treatments

\begin{tabular}{|c|c|c|c|c|}
\hline Group / Parameter & AST activity (IU/L) & ALT activity (IU/L) & GGT activity (IU/L) & ALP activity (IU/L) \\
\hline $\mathrm{C}$ & $6.83 \pm 3.70^{\mathrm{c}}$ & $40.17 \pm 2.96^{\mathrm{c}}$ & $1.87 \pm 0.07^{\mathrm{c}}$ & $218.3 \pm 9.46^{\mathrm{c}}$ \\
\hline $\mathrm{D}$ & $26.5 \pm 13.18^{\mathrm{a}}$ & $109.2 \pm 3.10^{\mathrm{a}}$ & $5.50 \pm 0.39^{\mathrm{a}}$ & $563.7 \pm 43.9^{\mathrm{a}}$ \\
\hline S & $158.8 \pm 9.0^{\mathrm{b}}$ & $51.83 \pm 3.20^{c}$ & $2.38 \pm 0.14^{\mathrm{c}}$ & $225.8 \pm 18.5^{\mathrm{c}}$ \\
\hline DSD & $183.7 \pm 6.2^{b}$ & $86.17 \pm 2.96^{\mathrm{b}}$ & $3.85 \pm 0.21^{\mathrm{b}}$ & $382.5 \pm 32.3^{\mathrm{b}}$ \\
\hline DHD & $165.2 \pm 6.5^{\mathrm{b}}$ & $75.83 \pm 2.97^{\mathrm{b}}$ & $3.47 \pm 0.17^{\mathrm{b}}$ & $330.7 \pm 26.3^{b}$ \\
\hline $\mathrm{SD}$ & $6.00 \pm 3.67^{\mathrm{c}}$ & $40.63 \pm 2.50^{c}$ & $1.60 \pm 0.08^{\mathrm{c}}$ & $224.2 \pm 7.12^{\mathrm{c}}$ \\
\hline HD & $63.0 \pm 3.66^{\mathrm{c}}$ & $40.38 \pm 2.52^{\mathrm{c}}$ & $1.56 \pm 0.11^{\mathrm{c}}$ & $226.8 \pm 0.11^{\mathrm{c}}$ \\
\hline Potential \% from standard (SD) & $71.0 \%$ & $40.1 \%$ & $52.9 \%$ & $53.6 \%$ \\
\hline Potential \% from standard (HD) & $93.1 \%$ & $58.2 \%$ & $65.2 \%$ & $68.9 \%$ \\
\hline
\end{tabular}

Values are presented as means \pm SE of 6 rats per group. Means within a column with different letter superscripts are significantly different $(P \leq 0.05$, ANOVA followed by Tukey's post-hoc). C: Control rats; D: Diseased rats; S: Standard, rats administrated with silymarin and carbon tetrachloride; DSD: Diseased rats treated with small dose of ABE; DHD: Diseased rats treated with high dose of ABE; SD and HD: Rats were given ABE only.

Table 2: The effect of Agaricus bisporus extract (ABE, 200 and $400 \mathrm{mg} / \mathrm{Kg}$, po, daily) and Silymarin (100 mg/Kg, po, daily) on total protein, albumin and globulin levels $(\mathrm{g} / \mathrm{dL})$ in plasma of normal and $\mathrm{CCl}_{4}$-intoxicated rats $(2.5 \mathrm{ml} / \mathrm{Kg}, 25 \%$, twice weekly) after 8 weeks of different treatments

\begin{tabular}{|c|c|c|c|}
\hline Group / Parameter & Total protein $(\mathrm{g} / \mathrm{dL})$ & Albumin (g/dL) & Globulins (g/dL) \\
\hline $\mathrm{C}$ & $6.52 \pm 0.15^{a}$ & $4.13 \pm 0.19^{\mathrm{a}}$ & $2.43 \pm 0.16^{\mathrm{a}}$ \\
\hline $\mathrm{D}$ & $2.17 \pm 0.09^{c}$ & $1.43 \pm 0.08^{c}$ & $0.76 \pm 0.06^{\mathrm{c}}$ \\
\hline $\mathrm{S}$ & $5.65 \pm 0.19^{\mathrm{a}}$ & $3.67 \pm 0.17^{\mathrm{a}}$ & $2.37 \pm 0.12^{\mathrm{a}}$ \\
\hline DSD & $3.78 \pm 0.37^{\mathrm{b}}$ & $2.53 \pm 0.14^{\mathrm{b}}$ & $1.43 \pm 0.11^{\mathrm{b}}$ \\
\hline DHD & $4.23 \pm 0.29^{b}$ & $2.65 \pm 0.15^{\mathrm{b}}$ & $1.63 \pm 0.19^{b}$ \\
\hline SD & $6.63 \pm 0.18^{a}$ & $4.17 \pm 0.19^{a}$ & $2.58 \pm 0.16^{\mathrm{a}}$ \\
\hline HD & $6.72 \pm 0.19^{\mathrm{a}}$ & $4.25 \pm 0.19^{\mathrm{a}}$ & $2.68 \pm 0.14^{\mathrm{a}}$ \\
\hline Potential \% from standard (SD) & $46.4 \%$ & $49.3 \%$ & $44.7 \%$ \\
\hline Potential \% from standard (HD) & $59.3 \%$ & $54.5 \%$ & $57.3 \%$ \\
\hline
\end{tabular}

Values are presented as means \pm SE of 6 rats per group. Means within a column with different letter superscripts are significantly different ( $P \leq 0.05$, ANOVA followed by Tukey's post-hoc). C: Control rats; D: Diseased rats; S: Standard, rats administrated with silymarin and carbon tetrachloride; DSD: Diseased rats treated with small dose of ABE; DHD: Diseased rats treated with high dose of ABE; SD and HD: Rats were given ABE only.

Table 3: The effect of Agaricus bisporus extract (ABE, 200 and $400 \mathrm{mg} / \mathrm{Kg}$, po, daily) and Silymarin (100 mg/Kg, po, daily) on total bilirubin, conjugated bilirubin and unconjugated bilirubin levels $(\mathrm{mg} / \mathrm{dL})$ in plasma of normal and $\mathrm{CCl}_{4}$-intoxicated rats $(2.5 \mathrm{ml} / \mathrm{Kg}, 25 \%$, twice weekly) after 8 weeks of different treatments

\begin{tabular}{llll}
\hline Group / Parameter & Total bilirubin (mg/dL) & Conjugated bilirubin (mg/dL) & Unconjugated bilirubin mg/dL) \\
\hline C & $0.48 \pm 0.03^{\mathrm{c}}$ & $0.13 \pm 0.02^{\mathrm{b}}$ & $0.36 \pm 0.02^{\mathrm{c}}$ \\
D & $1.04 \pm 0.04^{\mathrm{a}}$ & $0.24 \pm 0.02^{\mathrm{a}}$ & $0.89 \pm 0.08^{\mathrm{a}}$ \\
S & $0.67 \pm 0.01^{\mathrm{b}}$ & $0.15 \pm 0.01^{\mathrm{b}}$ & $0.49 \pm 0.02^{\mathrm{b}}$ \\
DSD & $1.02 \pm 0.06^{\mathrm{a}}$ & $0.19 \pm 0.02^{\mathrm{a}}$ & $0.85 \pm 0.07^{\mathrm{a}}$ \\
DHD & $0.74 \pm 0.01^{\mathrm{b}}$ & $0.17 \pm 0.02^{\mathrm{b}}$ & $0.57 \pm 0.01^{\mathrm{b}}$ \\
SD & $0.47 \pm 0.023^{\mathrm{c}}$ & $0.12 \pm 0.02^{\mathrm{b}}$ & $0.34 \pm 0.02^{\mathrm{c}}$ \\
HD & $0.46 \pm 0.03^{\mathrm{c}}$ & $0.14 \pm 0.01^{\mathrm{b}}$ & $0.33 \pm 0.03^{\mathrm{c}}$ \\
Potential \% from standard (SD) & $9.3 \%$ & $51.7 \%$ & $11.3 \%$ \\
Potential \% from standard (HD) & $81.8 \%$ & $81.0 \%$ & $80.0 \%$ \\
\hline
\end{tabular}

Values are presented as means \pm SE of 6 rats per group. Means within a column with different letter superscripts are significantly different $(P \leq 0.05$, ANOVA followed by Tukey's post-hoc). C: Control rats; D: Diseased rats; S: Standard, rats administrated with silymarin and carbon tetrachloride; DSD: Diseased rats treated with small dose of ABE; DHD: Diseased rats treated with high dose of ABE; SD and HD: Rats were given $\mathrm{ABE}$ only.

Table 4: The effect of Agaricus bisporus extract (ABE, 200 and $400 \mathrm{mg} / \mathrm{Kg}$, po, daily) and Silymarin (100 mg/Kg, po, daily) on lipid parameters (mg/dL) in plasma of normal and $\mathrm{CCl}_{4}$-intoxicated rats $(2.5 \mathrm{ml} / \mathrm{Kg}, 25 \%$, twice weekly) after 8 weeks of different treatments

\begin{tabular}{|c|c|c|c|c|c|}
\hline Group / Parameter & TAGs (mg/dL) & Cholesterol (mg/dL) & HDL (mg/dL) & LDL (mg/dL) & VLDL (mg/dL) \\
\hline $\mathrm{C}$ & $67.00 \pm 3.75^{\mathrm{c}}$ & $93.28 \pm 0.06^{\mathrm{c}}$ & $32.67 \pm 2.29^{\mathrm{a}}$ & $47.67 \pm 1.3^{\mathrm{d}}$ & $13.4 \pm 0.7^{\mathrm{c}}$ \\
\hline $\mathrm{D}$ & $157.7 \pm 3.88^{\mathrm{a}}$ & $196.7 \pm 4.41^{\mathrm{a}}$ & $10.25 \pm 0.77^{b}$ & $185.0 \pm 4.6^{\mathrm{a}}$ & $32.2 \pm 0.6^{\mathrm{a}}$ \\
\hline $\mathrm{S}$ & $81.33 \pm 2.94^{c}$ & $117.5 \pm 23.1^{\mathrm{b}}$ & $28.50 \pm 2.22^{\mathrm{b}}$ & $79.50 \pm 4.2^{\mathrm{c}}$ & $15.4 \pm 0.5^{\mathrm{c}}$ \\
\hline DSD & $111.0 \pm 3.07^{\mathrm{b}}$ & $129.2 \pm 3.50^{\mathrm{b}}$ & $13.83 \pm 30.8^{\mathrm{b}}$ & $106.3 \pm 4.2^{\mathrm{b}}$ & $21.8 \pm 0.7^{b}$ \\
\hline DHD & $100.0 \pm 3.42^{\mathrm{b}}$ & $125.0 \pm 2.92^{\mathrm{b}}$ & $25.00 \pm 1.90^{\mathrm{a}}$ & $95.83 \pm 3.2^{\mathrm{b}}$ & $20.0 \pm 0.7^{b}$ \\
\hline $\mathrm{SD}$ & $64.50 \pm 3.34^{c}$ & $93.18 \pm 0.65^{\mathrm{c}}$ & $33.70 \pm 2.30^{\mathrm{a}}$ & $46.00 \pm 1.1^{\mathrm{d}}$ & $13.1 \pm 0.7^{\mathrm{c}}$ \\
\hline HD & $64.83 \pm 3.85^{\mathrm{c}}$ & $93.38 \pm 0.67^{\mathrm{c}}$ & $34.15 \pm 2.09^{\mathrm{a}}$ & $44.80 \pm 0.9^{\mathrm{d}}$ & $13.0 \pm 0.8^{c}$ \\
\hline SD Pot. $\%$ & $61.2 \%$ & $85.2 \%$ & $19.6 \%$ & $74.6 \%$ & $63.57 \%$ \\
\hline HD Pot. \% & $75.5 \%$ & $90.4 \%$ & $80.8 \%$ & $84.5 \%$ & $78.77 \%$ \\
\hline
\end{tabular}

Values are presented as means \pm SE of 6 rats per group. Means within a column with different letter superscripts are significantly different $(P \leq 0.05$, ANOVA followed by Tukey's post-hoc). C: Control rats; D: Diseased rats; S: Standard, rats administrated with silymarin and carbon tetrachloride; DSD: Diseased rats treated with small dose of ABE; DHD: Diseased rats treated with high dose of ABE; SD and HD: Rats were given ABE only; TAGs, Triacylglycerols; HDL, High-density lipoprotein, LDL, Low-density lipoprotein, VLDL, Very lowdensity lipoprotein; Pot. \%, Potential \% from standard effect. 


\subsection{Oxidative stress parameters}

Results of the effects of ABE administration on oxidative stress markers are presented in Fig. 2a, b, c \& d.

A)

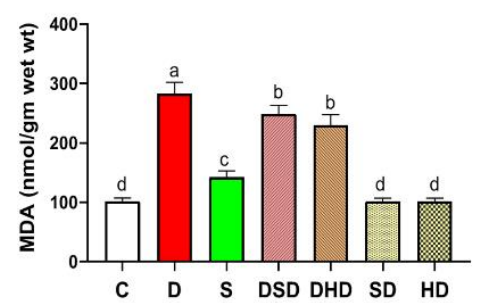

C)

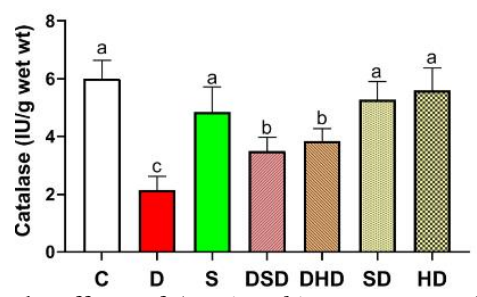

B)

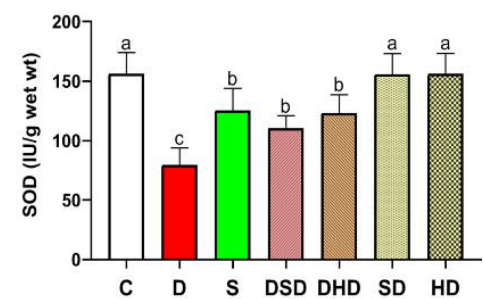

D)

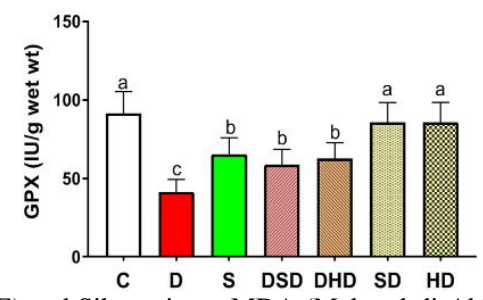

Fig. 2: Bar graph demonstrating the effects of Agaricus bisporus extract (ABE) and Silymarin on MDA (Malonyl-di-Aldehyde, nmol/g wet wt, A), SOD (Superoxide dismutase, IU/g wet wt, B), Catalase (IU/g wet wt, C) and GPx (Glutathione peroxidase, IU/g wet wt, D) in liver tissue homogenate of normal and Carbon tetrachloride-intoxicated rats after 8 weeks of different treatments. Values are presented as Means \pm SE of 6 rats/group. Bars with different letters are significantly different $(P \leq 0.05$, ANOVA followed by Tukey's post-hoc test). C: Control, rats received only vehicles; D: Diseased, rats given $\mathrm{CCl}_{4}\left(2.5 \mathrm{ml} / \mathrm{Kg}, 25 \%\right.$, ip, twice weekly); S: Standard, rats administrated with $\mathrm{CCl}_{4}$ and Silymarin (100 mg/Kg, po, daily); DSD: Diseased rats treated with small dose (200 mg/Kg, po, daily) of ABE; DHD: Diseased rats treated with high dose (400 mg/Kg, po, daily) of ABE; SD and HD: Normal rats given only $\mathrm{ABE}$ at small and high doses, respectively.

\subsection{Pathological findings}

As shown in Fig. 3-a, gross examination revealed that the livers of rats within the control group received only vehicles (normal saline, po; corn oil, ip) showed deep red color, soft, smooth and shiny surface texture with no abnormalities. While the livers of rats within diseased group (given carbon tetrachloride, $2.5 \mathrm{ml} / \mathrm{kg}, 25 \%$, ip, twice weekly) for 8 weeks, showed grey-red color, loss of luster and fatty deposits, with a yellowed rough surface, blunt edges and slight swelling (Fig. 3-b). In contrast, the livers of diseased rats but treated concurrently with silymarin $(100 \mathrm{mg} / \mathrm{kg}$, po, once daily) for 8 weeks were comparatively healthier, with bright, shiny, deep red color and smooth surfaces (Fig. 3-c). The livers of diseased rats treated with $\operatorname{ABE}(200,400 \mathrm{mg} / \mathrm{kg}$, po, once daily) for 8 week showed dose-dependent obvious signs of recovery as red color, moist, low fatty deposits, capsule smooth, complete, and a soft texture of liver (Fig. 3-d \& 3-e). The livers of normal rats given only $\mathrm{ABE}$ ( 200 or $400 \mathrm{mg} / \mathrm{kg}$, po, once daily) for 8 week showed deep red color, soft, smooth and shiny surface texture with no abnormalities (Fig. 3-f, only that treated with HD is presented).

Microscopically, no histopathological changes were detected in the examined livers obtained from control group as the liver showed normal histological criteria of blood vessels, bile ducts and hepatic cords (Fig. 4a). The livers of rats treated with $\mathrm{CCl}_{4}$ showed congestion and dilatation of central and portal veins, the blood sinusoids were occasionally dilated and congested with activation of Kuepfer cells. The portal areas were moderately expanded by aggregates of inflammatory cells around hyperplasia of the lining epithelium of bile duct with peri-portal proliferation of fibrous connective tissue (Fig. 4b). Furthermore, ectatic bile duct with newly formed bile ductules as well as periductal fibrosis infiltrated by mononuclear inflammatory cells were observed. Extensive degenerative changes, including, hydropic degeneration and fatty change that characterized by swollen, pale, vacuolated cytoplasm were demonstrated in the hepatocytes (Fig. 4c). Occasionally, focal areas of coagulative necrosis, characterized by retention of hepatic cord architecture, shrunken hepatocytes with hypereosinophilic cytoplasm and pyknotic nuclei in association with leukocytic cellular infiltration were detected. Additionally, diffuse areas of lytic necrosis characterized by replacement of the hepatic parenchyma with cellular and karyorrhectic debris admixed with fibrin and inflammatory cells were also demonstrated (Fig. 4d). Multifocally, there were variable size strands of fibrous connective tissue infiltrated by mononuclear inflammatory cells that replacing the hepatic parenchyma. The proliferated fibrous connective tissue was frequently seen adjacent to degenerated hepatocytes, around the central vein and in portal areas. Fibrous connective tissue proliferation in between the hepatic lobules with distinct nodular pattern which separate the hepatic lobules from each other resulting in formation of pseudo-lobulation (Fig. 4e) at which fibrous septa appeared thick and contained proteinaceous eosinophilic edematous substance admixed with mononuclear inflammatory cells (Fig. 4f).

Meanwhile, the microscopical examination of the livers obtained from rats treated with Silymarin revealed mild degeneration of the hepatocytes, characterized by enlargement of the cells by multiple variably sized discrete empty vacuoles that distend the cell cytoplasm were observed (Fig. 5a). The prominent microscopical findings in the liver were marked reduction in the intensity and spreading of fibrous tissue proliferation that appeared as thin strands in between hepatic lobules in most examined sections was detected (Fig. 5b). Interestingly, normal portal area was demonstrated.

However, the histopathological examination of livers obtained from animals treated with $\mathrm{CCl}_{4}$ and small dose of $\mathrm{ABE}$ for 8 weeks revealed less prominent histopathological changes when compared with the group treated with $\mathrm{CCl}_{4}$ alone for the same period. Focal areas of vacuolar and hydropic degeneration in the hepatocytes mainly periphero-lobular (Fig. 5c) with expansion of the portal areas with few inflammatory cells mainly lymphocytes and fewer macrophages. Multifocally, there were remnant of small sized discrete strands of fibrous connective tissue proliferation in the hepatic parenchyma (Fig. 5d). The proliferated fibrous tissue was infiltrated and rimmed by mononuclear inflammatory cells. 
Concerning the histopathological examination of livers obtained from rats of group 5 that received $\mathrm{CCl}_{4}$ and high dose of $\mathrm{ABE}$ for 8 weeks revealed restoration of the hepatic parenchymal cells, as mild congestion of the central vein and hepatic sinusoid. Nearly normal histological structures of the portal area Moreover, mild degenerative changes in the hepatocytes particularly fatty change as the hepatocytes have multiple variably sized small discrete intracytoplasmic clear vacuoles was observed (Fig. 5e). However, marked reduction in the intensity and spreading of fibrous tissue proliferation that appeared as thin strands of the fibrous connective tissue in between hepatic lobules in only two examined cases. Finally, liver specimens from groups $6 \& 7$ that received ABE only at small or high dose showed normal hepatic histological structures (Fig. 5f; only that of high dose group is presented).
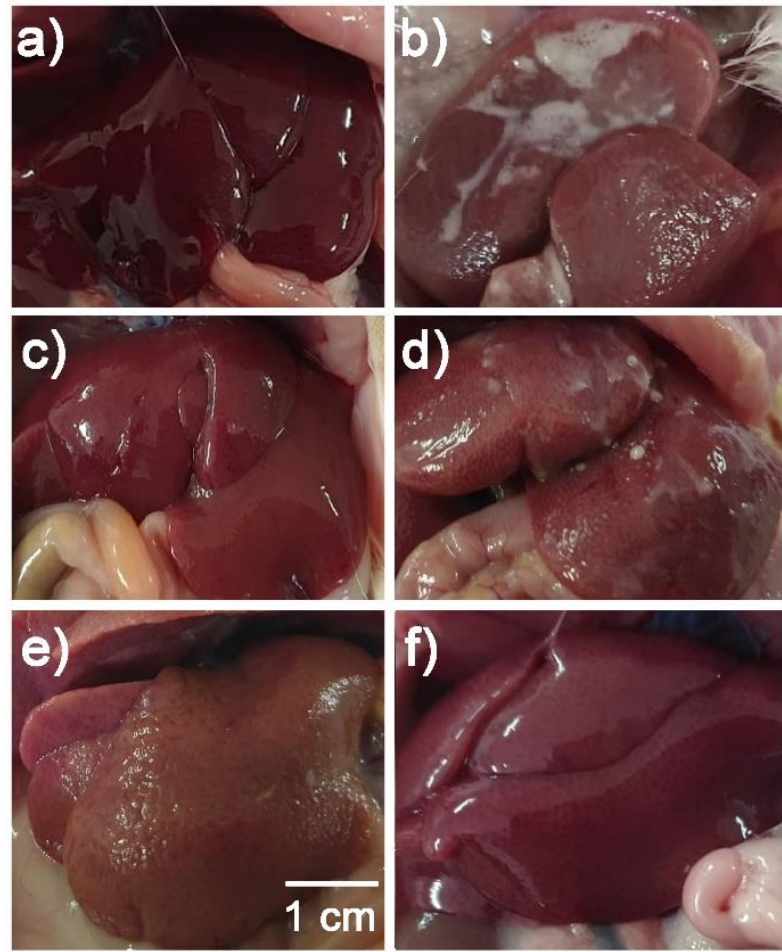

Fig. 3: Macroscopic picture of livers obtained from rats of Control (A), $\mathrm{CCl}_{4}$-treated (B), $\mathrm{CCl}_{4}+\mathrm{Silymarin}_{\text {-treated }}(\mathrm{C}), \mathrm{CCl} \mathrm{Cl}_{4}+\mathrm{ABE} \mathrm{SD-treated}(\mathrm{D}), \mathrm{CCl}_{4}$ + ABE HD-treated (E), ABE HD (F), showing: (A) no abnormalities, (B) grey-red color, loss of luster and fatty deposits, with a yellow rough surface, blunt swollen edges, (C) showing deep red, moist, glossy, capsule smooth, complete, and a soft texture of liver, (D) faint red, moist, less fatty deposits, complete, and a soft texture of liver, (E) marked restoration of the liver manifested by deep red, moist, capsule smooth, complete, and a soft texture, (F) normal-like liver with no abnormalities.

\section{Discussion}

Drug-induced liver disease covers a broad spectrum, from acute hepatic necrosis, chronic hepatitis, and vascular injury to bile ductular injury and neoplasms. A role of drugs in liver injury can also be suggested by the characteristic time interval between the administration of the suspected toxin and onset of the injury. Co-existing liver disease also can impact the pattern of injury. The most feared pattern of injury is massive necrosis, presenting as acute liver failure (ALF). About 2,000 cases of ALF occur annually, often in the relatively young and in women (75\% of the total). More than $50 \%$ of ALF cases in the United States are due to drug toxicity: $36 \%$ from acetaminophen and $16 \%$ idiosyncratic drug reactions (Bissell et al. 2001).

Availability of simulating liver disease models is a must to discover hepatoprotectives. Many chemicals are known to induce liver injury and thus are commonly used to prepare experimental animal models to understand pathogenesis of liver disease and to evaluate the possibility of future remedies.

$\mathrm{CCl}_{4}$ was discovered in 1839 and was used later as a competitor to chloroform but was rejected as too toxic. It was resurrected as an anthelmintic against hookworm. Next, its power as a solvent have been widely applied to industrial uses. Its toxic power is described, particularly on the liver and kidneys. Probably its toxicity depends largely on its power of dissolving fats, whereby it causes necrosis of the central part of the liver lobule (Hardin Jr 1954). So, hepatic damage by $\mathrm{CCl}_{4}$ exposure is one of the most common models for hepatoprotective drug development. $\mathrm{CCl}_{4}$ induces hepatotoxicity after metabolic activation, where it binds to cytochrome $\mathrm{P} 450$ reductase. The enzyme substrate complex then loses a chloride ion and a free radical $\left(\mathrm{CCl}_{3}\right.$.) intermediate is generated which reacts with oxygen or takes a hydrogen from a donor to yield a secondary radical or reacts with lipids or proteins. The lipid radicals thus formed add on molecular oxygen to generate lipid peroxyl radicals, which take the hydrogen atoms from other lipid molecules and the process of lipid peroxidation propagates. Trichloromethyl $\left(\mathrm{CCl}_{3}\right.$.) radical even reacts with reduced glutathione $(\mathrm{GSH})$ and causes various pathological and toxicological manifestations. $\mathrm{CCl}_{4}$ increases intercellular $\mathrm{Ca} 2+$ concentration and activates Kupffer cells, there by releasing harmful cytokines that leads to the death of the hepatic tissue and oxidative stress (Acharya et al. 2012).

Antioxidants play a crucial role in hepatoprotective ability and hence the search for crude drugs of natural origin with this property has become a central focus of study of hepatoprotection today. Antioxidative action plays an important role in protecting the liver against $\mathrm{CCl}_{4}-$ induced liver injury. The usage of herbal drugs for the treatment of liver diseases has increased all over the world. Developing therapeutically effective agents from natural products may reduce the risk of toxicity when the drug is used clinically.

Among the most common antioxidant and thus hepatoprotective agents is Silymarin which is a natural compound derived from the species Silybum marianum. The hepatoprotective and antioxidant activity of silymarin is caused by its ability to inhibit the free radicals that are produced from the metabolism of toxic substances such as ethanol, acetaminophen, and $\mathrm{CCl}_{4}$. Silymarin enhances hepatic glutathione and may contribute to the antioxidant defense of the liver (Vargas-Mendoza et al. 2014). 


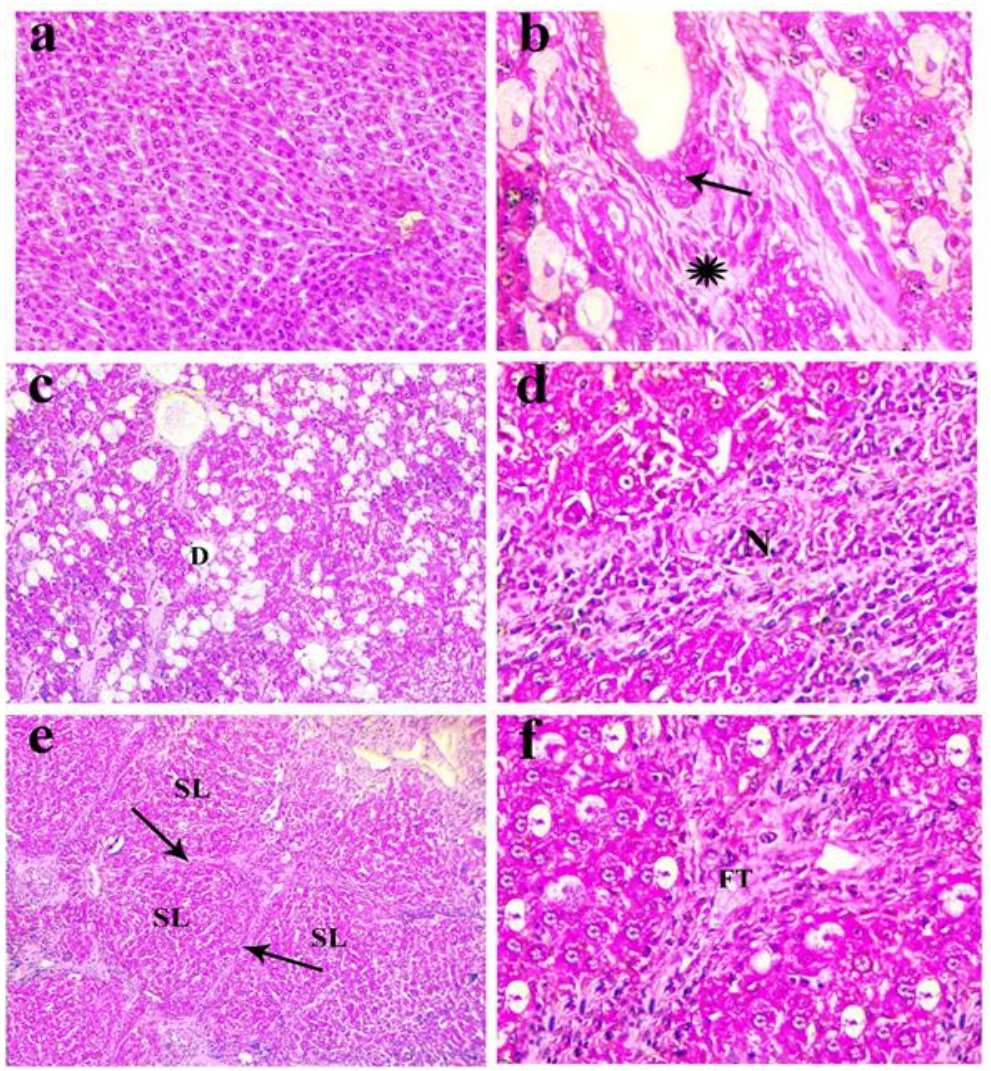

Fig. 4: H\&E stained sections of livers obtained from rats of Control group (A), Group 2 (E-F), showing: (A) normal histological criteria of hepatocyte (X 200), (B) hyperplasia of the biliary epithelium (arrow) with peri-portal fibrosis (asterisk) infiltrated by mononuclear inflammatory cells (X400), (C) extensive degenerative changes in the hepatocytes (D, X100), (D) diffuse area of lytic necrosis $(\mathrm{N})$ characterized by replacement of the hepatic parenchyma with cellular and karyorrhectic debris with fibrin and inflammatory cells (X400), (E) strands of fibrous connective tissue proliferation (arrow) forming pseudolobulation (SL) in the hepatic parenchyma (X 100), (F) fibrous connective tissue proliferation admixed with eosinophilic proteinaceous substances (FT) replacing the hepatic parenchyma (X 400).
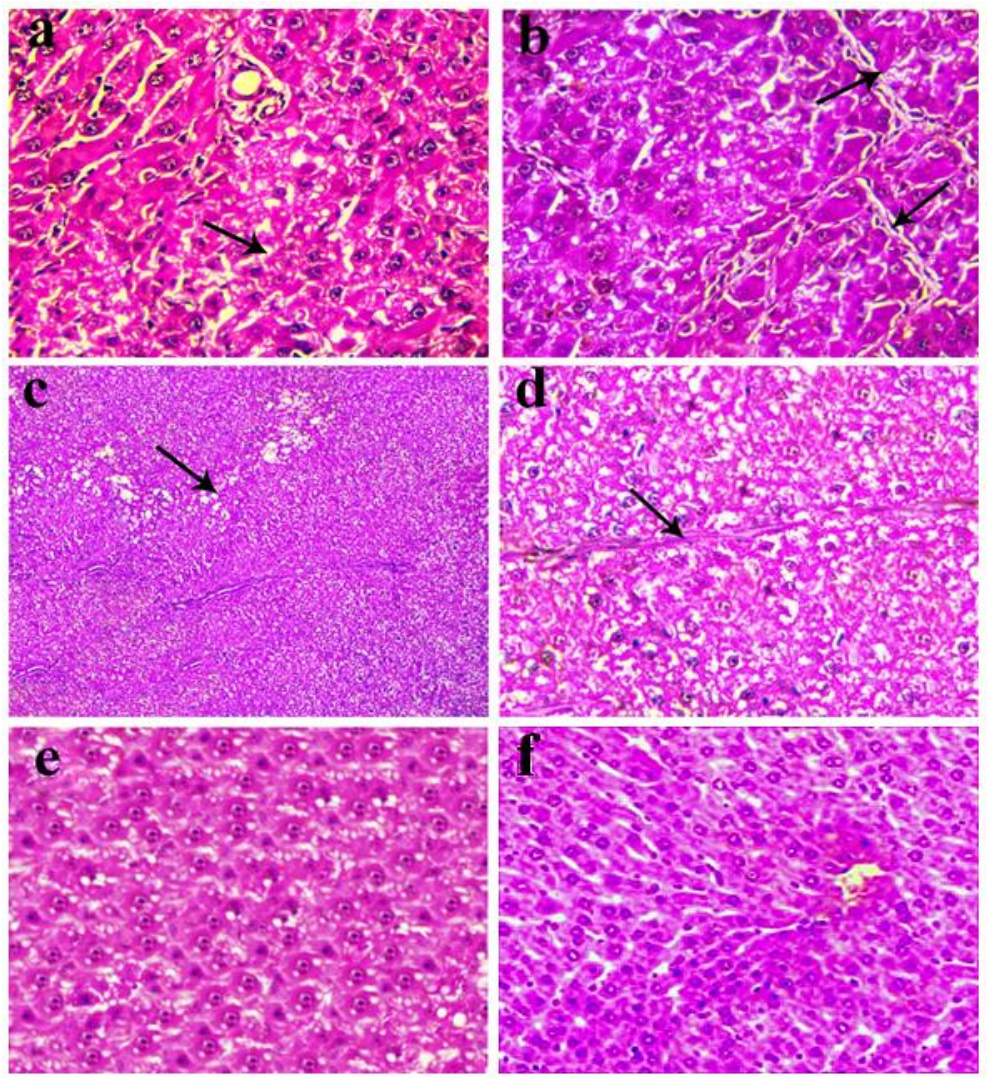

Fig. 5: H\&E stained section of livers obtained from rats of Group 3 (A-B), Group 4 (C-D), Group 5 (E) and Group 7 (F) showing: (A) degeneration of hepatocytes characterized by swollen, pale, vacuolated cytoplasm (arrow) with normal portal area (X400), (B) fine strands of fibrous connective tissue (arrow) adjacent to the degenerated hepatocytes (D, X400), (C) periphero-lobular degenerative changes in the hepatocytes (arrow) with fine strands of fibrous connective tissue (X100), (D) fine strands of fibrous connective tissue adjacent to the degenerated hepatocytes (arrow, X400), (E) mild fatty change in the hepatocytes (X400), (F) normal histological criteria of hepatocyte with very mild congestion (X 400). 
More than one trial has been done to find out Silymarin-like drug. Researchers at the Pennsylvania State Mushroom Research Laboratory found that mushrooms contain significant levels of Ergothioneine, which has shown antioxidant properties as a scavenger of strong oxidants (Al-Dbass et al. 2012). Feng et al. (2020) stated that Agaricus bisporus (A. bisporus), known as a cultivated mushroom or button mushroom, is a very important edible and medicinal basidiomycete fungus. The numerous health benefits of $A$. bisporus may be related to their polysaccharides, which have significant dietary value and bioactivity, including immunity stimulation and high antioxidant, hepatoprotection, anti-inflammation and anti-obesity functions.

The effect of Agaricus bisporus species that is growing in Egypt, as a liver supportive agent has not been studied yet. The present study discusses the hepatoprotective properties of Agaricus bisporus (one among mushrooms) in context of its antioxidant properties.

\subsection{Liver function parameters}

In the present study, liver enzymatic markers (ALT, AST, ALP, and GGT) have significantly increased in the group intoxicated with $\mathrm{CCl}_{4}$ $25 \%(2.5 \mathrm{ml} / \mathrm{kg})$ as presented in table1. However, co-administration of ABE (200 and $400 \mathrm{mg} / \mathrm{kg}$ ) along with CCl 4 for 8 weeks resulted in dose-dependent significant $(P \leq 0.05)$ decrease in plasma (AST, AST, ALP, and GGT) activities, compared to the hepato-intoxicated group, with potentials of $93.1,58.2,68.9$ and $65.2 \%$ of silymarin, respectively. Even though, ABE alone has no significant modulatory effects on liver enzymatic markers.

These effects may be attributed to the antioxidant potential of ABE that is proved later in the present study.

These findings may be consistent with those of Liu et al. (2018) who reported that aqueous extract of Agaricus bisporus at dose of $0.5 \mathrm{~g} / \mathrm{kg}$ body weight daily, decreased the liver index, serum GGT, ALT, ALP, and AST activities in the $\mathrm{CCl}_{4}$-treated by necrogenic dose (1.5 ml/kg body weight of $80 \% \mathrm{CCl}_{4}$ in corn oil) in rats model.

On the other hand, the findings may be inconsistent with those of Chang et al. (2011) who found that Agaricus blazei at high dose 2000 $\mathrm{mg} / \mathrm{kg}$ produced slightly elevated serum AST and ALT levels in mice model treated by $40 \% \mathrm{CCl}_{4} / \mathrm{olive}$ oil (1 ml/kg body weight per day, i.p. twice per week for 8 weeks) in comparison with the negative control group. These differences among our data and those of the abovementioned researchers could be attributed to different methodological and environmental conditions, including, model, species of Agaricus, dose of extract and hepatotoxin, extraction procedures...etc.

In the present study, plasma proteins (total, albumin and globulins) have been decreased significantly in the rats intoxicated with $\mathrm{CCl}_{4} 25 \%$ $(2.5 \mathrm{ml} / \mathrm{kg})$ in table 2. However, co-administration of $\mathrm{ABE}(200$ and $400 \mathrm{mg} / \mathrm{kg})$ along with $\mathrm{CCl}_{4}$ for 8 weeks resulted in dose-dependent significant $(P \leq 0.05)$ increase in plasma protein levels, compared to the hepato-intoxicated group, with potentials of 59.3, 54.5 and 57.3 $\%$ of silymarin, respectively. However, ABE alone did not affect protein parameters.

These finding may be partially consistent with those of Bastos et al. (2016) who found that animals (sheep model) treated with trichlorfon $(10 \mathrm{mg} / \mathrm{g} \mathrm{bw})$ and Agaricus blazei $(11.14 \mathrm{~g} / \mathrm{kg}$ bw) showed progressive recovery of albumin, globulins, and total protein concentrations, returning to the baseline level after 21 days, unlike that in the control group received trichlorfon only.

However, our findings may be inconsistent with those of Junior et al. (2016) who found that Agaricus blazei extract (2.5 g/kg bw) given for 21 days to albino mice has no significant differences in the levels of serum concentrations of total protein, albumin, and inhibited the increase of gamma-globulin with Ehrlich tumor that is associated with marked decrease in albumin (thus, is considered to be a protein of the negative acute phase) and other protein fractions. These differences could be attributed to different methodological and environmental conditions, including, model, dose of extract and hepatotoxin, extraction procedures, and species of Agaricus used.

In the present study, total bilirubin, conjugated bilirubin and unconjugated bilirubin increased significantly in the rat group intoxicated with $\mathrm{CCl}_{4} 25 \%(2.5 \mathrm{ml} / \mathrm{kg})$ as shown in table 3. However, administration of $\mathrm{ABE}(400 \mathrm{mg} / \mathrm{kg})$ only along with CCl 4 for 8 weeks resulted a significant $(P \leq 0.05)$ increase in plasma bilirubin levels, compared to the hepato-intoxicated group, with potentials of $81.8,81.0$ and 80.0 $\%$ of silymarin, respectively. Even though, ABE alone was without effect on bilirubin markers.

These finding may be in partial consistence with those of Shekhany et al. (2012), who found that Agaricus bisporus aqueous extract (500 $\mathrm{mg} / \mathrm{kg}$ ) significantly decreased serum total bilirubin which had been greatly increased by Zearalenon (ZEA; $2.4 \mathrm{mg} / \mathrm{kg}$ b.w.) which had hepatotoxic effect compared to control mice. While the mean differences of serum total bilirubin between control group and animals treated with combination of ZEA and mushroom extract were non-significant. In contrast, our findings may be inconsistent with those of Nieminen et al. (2009) who found that aqueous extract of Agaricus bisporus $(9 \mathrm{~g} / \mathrm{kg}$ bw) significantly increased plasma bilirubin concentrations compared to normal control. This discrepancy could be explained on the basis of methodological and environmental differences.

In the current study, plasma levels of triglycerides, total cholesterol, LDL and VLDL have been significantly increased, while that of HDL has been decreased in the group intoxicated with $\mathrm{CCl}_{4} 25 \%(2.5 \mathrm{ml} / \mathrm{kg})$ as presented in table 4 . However, co-administration of $\mathrm{ABE}(200$ and $400 \mathrm{mg} / \mathrm{kg}$ ) along with $\mathrm{CCl}_{4}$ for 8 weeks resulted in dose-dependent significant $(P \leq 0.05)$ decrease in plasma (triglycerides, total cholesterol, LDL and VLDL) levels, while plasma HDL was restored only upon administration of Agaricus extract (400 mg/kg) only, compared to the hepato-intoxicated group, with potentials of $75.5,90.4,84.5,78.7 \%$ and $80.8 \%$ of silymarin, respectively. Again, ABE alone did not affect lipid profile of normal rats.

These lipid profile findings may be in partial agreement with those of Kanaya et al. (2011) who found that white button mushroom (Agaricus bisporus) at dose of (120 g powder $/ \mathrm{kg}$ ) reduced the cholesterol level in serum and liver in a mouse model of postmenopausal women (seven-week old, female mice were ovariectomized and fed a high fat diet, $45 \% \mathrm{wt} / \mathrm{wt}$ fat diet). The authors concluded that Agaricus bisporus, has protective effects against liver steatosis in ovariectomized mice characterized by lowered liver weight and hepatic injury markers. Also, data of the present study may be consistent with those of Jeong et al. (2010) who found that Agaricus bisporus powder (ABP; $200 \mathrm{mg} / \mathrm{kg}$ of body weight) for 4 weeks resulted in a significant decrease in plasma total cholesterol (TC) and low-density lipoprotein (LDL) $(22.8 \%$ and $33.1 \%$, respectively) $(\mathrm{P}<.05)$ in rats with type 2 diabetes induced by injection of streptozotocin (STZ) $(50 \mathrm{mg} / \mathrm{kg}$ body weight).

In contrast, our results may be inconsistent with those of Khudhair (2018) who reported a significant increase in cholesterol (CH) in female albino mice the received $2 \mathrm{ml} / \mathrm{kg}$ body weight of peroxide used as a toxicant (second group) and mice received $2 \mathrm{ml} / \mathrm{kg}$ body weight of peroxide plus $25 \mathrm{mg} / \mathrm{ml}$ A bisporus (third group), while there was no significant decrease in CH level of mice received $25 \mathrm{mg} / \mathrm{ml}$ of A. bisporus (fourth group) as compared with control group (first group). As well, there was a significant increase in Low Density Lipoprotein (LDL) in second and third groups, while there was a significant decrease in fourth group as compared with the control one. Differences among our data and those of the above-mentioned researchers could be attributed to different methodological and environmental conditions, including, model, dose of extract and hepatotoxin, extraction procedures.

Generally, all the above-mentioned improvements of Agaricus bisporus extract could be explained on the basis of its antioxidant effect that is proved in the present study and discussed below. 


\subsection{Oxidative stress parameters}

Malondialdehyde (MDA) is the end product of the lipid peroxidation, while SOD, CAT and other antioxidants are involved in the elimination of free radicals. They are assumed to represent pro-oxidant and antioxidant factors respectively in the cellular free radical metabolism. The balance of these two decide the net result of cellular and/or tissue oxidation/peroxidation state (Pujar et al. 2011).

In the current study, activities of anti-oxidant enzymes (SOD, CAT and GPX) in liver tissue homogenate were significantly decreased; while the oxidative stress marker (MDA) level in the homogenate was found significantly higher in the group intoxicated with $\mathrm{CCl}_{4} 25 \%$ $\left(2.5 \mathrm{ml} / \mathrm{kg}\right.$ ) as presented in figure 2. However, co-administration of ABE (200 and $400 \mathrm{mg} / \mathrm{kg}$ ) along with $\mathrm{CCl}_{4}$ resulted in dose-dependent significant $(P \leq 0.05)$ increase in liver (SOD, Catalase and GPX) activities and administration of ABE $(400 \mathrm{mg} / \mathrm{kg})$ only along with CCl 4 for 8 weeks resulted in a significant $(P \leq 0.05)$ decrease in MDA of the homogenate, compared to the hepato-intoxicated group, with potentials of $94.9,63.0,88.4 \%$ and $37.9 \%$ of silymarin, respectively. Even though, ABE alone did not affect the measured oxidative stress markers significantly.

Our findings may be consistent with those of Liu et al. (2018) who found that Agaricus bisporus polysaccharide at dose (0.5 g/kg body weight daily) significantly decreased MDA contents in liver injured by $\mathrm{CCl}_{4}\left(1.5 \mathrm{ml} / \mathrm{kg}\right.$ body weight of $\left.80 \% \mathrm{CCl}_{4}\right)$ in mice model, while increased antioxidant capacities of hepatic GPx and SOD. Also, data of the present study may be consistent with those of Al-Dbass et al. (2012) who found that the production of MDA was increased in $\mathrm{CCl}_{4}$-treated rats $\left(1.5 \mathrm{ml} / \mathrm{kg}\right.$ body weight of $\left.80 \% \mathrm{CCl}_{4}\right)$ unlike what was found in animals treated with Agaricus blazei Muril at dose of $0.5 \mathrm{~g} / \mathrm{kg}$ body weight daily.

On the other hand, data of the present study may be inconsistent with those of Chang et al. (2011) who found that post-treatment with ethanolic extract of Agaricus blazei Murrill at dose $(200 \mathrm{mg} / \mathrm{kg}$ body weight) did not significantly reverse the alterations of GPx and catalase caused by $\mathrm{CCl}_{4}\left(1.5 \mathrm{ml} / \mathrm{kg}\right.$ body weight of $\left.80 \% \mathrm{CCl}_{4}\right)$ in mice. These differences among our data and those of the above-mentioned researchers could be attributed to different methodological and environmental conditions, including, model, dose of extract and hepatotoxin, extraction procedures.

\subsection{Pathological findings}

Pathological observations presented above in the "Results" section, may be consistent with those of Ali et al. (2018) who found that aqueous extract $(25 \mathrm{mg} / \mathrm{ml}$ in drinking water) of $A$. bisporus protected against acute hepatotoxicity in mice induced by $2 \mathrm{ml} / \mathrm{kg}$ body weight of peroxide $\left(\mathrm{H}_{2} \mathrm{O}_{2}\right)$ indicated by reduced mononuclear cells (neutrophils and monocytes) aggregation. Also, the present observations may be consistent with those of Chang et al. (2011) who found that the broad cavitation and fibrosis in liver caused by $\mathrm{CCl}_{4}(1.5 \mathrm{ml} / \mathrm{kg} \mathrm{body} \mathrm{weight}$ of $\left.80 \% \mathrm{CCl}_{4}\right)$ in mice were greatly reduced upon treatment with $(200 \mathrm{mg} / \mathrm{kg}$ body weight $)$ of Agaricus blazei extract. In contrast, findings of the present study may be inconsistent with those of Soares et al. (2013) who found that liver damages caused by paracetamol (2 g/kg body weight) were not significantly modified by $(200 \mathrm{mg} / \mathrm{kg}$ body weight) of Agaricus blazei extract pretreatment in mice model; where both groups showed a damaged liver architecture in the form of twisted cords of hepatocytes and veins, disorganized parenchyma, inflammatory infiltrates around the central veins, with the presence of neutrophils and monocytes.

\section{Conclusion}

In conclusion, the data achieved by this study revealed that Agaricus bisporus is a good antioxidant and hepatoprotective agent against carbon tetrachloride-induced liver injury in rats, which would be exploited as a potentially natural nutraceutical for hepatic protection.

\section{Declaration}

Conflict of interest: There is no actual or potential conflict of interest in relation to this article.

\section{References}

[1] Acharya K, Chatterjee S, Biswas G, Chatterjee A, Saha GK (2012). Hepatoprotective effect of a wild edible mushroom on carbon tetrachlorideinduced hepatotoxicity in mice. International Journal of Pharmacy and Pharmaceutical Sciences 4, 285-288.

[2] Aebi H (1984). Catalase in vitro. Methods Enzymol 105, 121-126. https://doi.org/10.1016/S0076-6879(84)05016-3.

[3] Al-Dbass AM, Al-Daihan SK, Bhat RS (2012). Agaricus blazei Murill as an efficient hepatoprotective and antioxidant agent against CCl4-induced liver injury in rats. Saudi journal of biological sciences 19, 303-309. https://doi.org/10.1016/j.sjbs.2012.03.004.

[4] Ali DK, Al-Bahrani R, Majeed SA (2018). The Protective Role of Agaricus bisporus in Experimental Liver Injury in Mice. IOSR Journal of Pharmacy and Biological Sciences 13, 23-28.

[5] Bancroft JD, Gamble M (2008). Theory and practice of histological techniques: Elsevier health sciences.

[6] Bas CF, Marks R (1991). The layered perceptron versus the Neyman-Pearson optimal detection. In: Proc. Int. Joint Conf. Neural Networks. p 14861489. https://doi.org/10.1109/IJCNN.1991.170610.

[7] Bastos GA, Soares ACM, Vieira TM, de Souza Cândido RC, Morais-Costa F, de Oliveira Vasconcelos V, Oliveira NJF, Duarte ER (2016). Blood parameters of sheep with high infection of Haemonchus contortus and treated with "mushroom of the sun" (Agaricus blazei). Semina: Ciências Agrárias 37, 807-818. https://doi.org/10.5433/1679-0359.2016v37n2p807.

[8] Belfield A, Goldberg D (1971). Revised assay for serum phenyl phosphatase activity using 4-amino-antipyrine. Enzyme 12, 561-573. https://doi.org/10.1159/000459586.

[9] Bell LN, Chalasani N (2009). Epidemiology of idiosyncratic drug-induced liver injury. In: Seminars in liver disease: (C) Thieme Medical Publishers. p 337-347. https://doi.org/10.1055/s-0029-1240002.

[10] Bhushan A, Kulshreshtha M (2018). The medicinal Mushroom Agaricus bisporus: Review of phytopharmacology and potential role in the treatment of various diseases. Journal of Nature and Science of Medicine 1, 4

[11] Bissell DM, Gores GJ, Laskin DL, Hoofnagle JH (2001). Drug-induced liver injury: mechanisms and test systems. Hepatology 33, $1009-1013$. https://doi.org/10.1053/jhep.2001.23505.

[12] Busher JT (1990). Serum albumin and globulin. Clinical methods: The history, physical, and laboratory examinations 3, 497-499.

[13] Chang J-B, Wu M-F, Yang Y-Y, Leu S-J, Chen Y-L, Yu C-S, Yu C-C, Chang S-J, Lu H-F, Chung J-G (2011). Carbon tetrachloride-induced hepatotoxicity and its amelioration by Agaricus blazei Murrill extract in a mouse model. in vivo 25, 971-976.

[14] Del Maestro R, McDonald W (1985). Oxidative enzymes in tissue homogenates: Boca Raton, FL, CRC Press. 
[15] Doumas BT, Watson WA, Biggs HG (1971). Albumin standards and the measurement of serum albumin with bromcresol green. Clinica chimica acta 31, 87-96. https://doi.org/10.1016/0009-8981(71)90365-2.

[16] El-Mahmoudy AM, Abdel-Fattah FA, Abd El-Mageid AD, Gheith IM (2014). Effect of the growth promotant mannan-oligosaccharide on the lipogram and organ function profile in hyperlipidemic albino rats. Am. J. Phytomed. Clin. Ther 2, 334-347.

[17] Fassati P, Prencipe L (1982). Serum triglycerides determined colorimetrically with an enzyme that produces hydrogen peroxide. Clin Chem 28, 20772080. https://doi.org/10.1093/clinchem/28.10.2077.

[18] Feng Y, Zhang J, Wen C, Dzah CS, Juliet IC, Duan Y, Zhang H (2020). Recent advances in Agaricus bisporus polysaccharides: Extraction, purification, physicochemical characterization and bioactivities. Process Biochemistry. https://doi.org/10.1016/j.procbio.2020.04.010.

[19] Gheith I, El-Mahmoudy A (2018). Laboratory evidence for the hematopoietic potential of Beta vulgaris leaf and stalk extract in a phenylhydrazine model of anemia. Brazilian Journal of Medical and Biological Research 51. https://doi.org/10.1590/1414-431x20187722.

[20] Gornall A (1949). Bardawill CJ, and David MM. Determination of serum proteins by means of the biuret reaction. J Biol Chem 177, 751-766.

[21] Harborn J (1973). Photochemical methods. Hasted Presses. In: John Wiley and Sons, New York.

[22] Hardin Jr B (1954). Carbon Tetrachloride Poisoning-a Review. Industrial Medicine and Surgery, 93-105.

[23] Hong Y-C (2019). Method of Ending Disease and the Future Medical System. The Changing Era of Diseases, 109. https://doi.org/10.1016/B978-012-816439-6.00004-1

[24] Jeong SC, Jeong YT, Yang BK, Islam R, Koyyalamudi SR, Pang G, Cho KY, Song CH (2010). White button mushroom (Agaricus bisporus) lowers blood glucose and cholesterol levels in diabetic and hypercholesterolemic rats. Nutrition research 30, 49-56. https://doi.org/10.1016/j.nutres.2009.12.003.

[25] Junior DV, de Oliveira NJF, Duarte ER, Bastos GA, Soares ACM, Cassali GD, Soto-Blanco B, Melo MM (2016). Serum hepatic biochemistry and electrophoretic protein profile of healthy and Ehrlich tumor-bearing mice treated with extracts of Agaricus blazei Murill. Semina: Ciências Agrárias 37, 763-772. https://doi.org/10.5433/1679-0359.2016v37n2p763.

[26] Kanaya N, Kubo M, Liu Z, Chu P, Wang C, Yuan Y-C, Chen S (2011). Protective effects of white button mushroom (Agaricus bisporus) against hepatic steatosis in ovariectomized mice as a model of postmenopausal women. PLoS One 6, e26654. https://doi.org/10.1371/journal.pone.0026654.

[27] Karaman M, Mimica-Dukic N, Knezevic P, Svircev Z, Matavuly M (2009). Antibacterial properties of selected lignicolous mushrooms and fungi from northern Serbia. International Journal of Medicinal Mushrooms 11. https://doi.org/10.1615/IntJMedMushr.v11.i3.60.

[28] Khan M, Tania M, Zhang D, Chen H (2010). Cordyceps mushroom: a potent anticancer nutraceutical. The Open Nutraceutical Journal 3, 179. https://doi.org/10.2174/18763960010030100179.

[29] Khudhair DHA (2018). Effect of aqueous extract of Agaricus bispporus on lipid profile of female albino mice treated with peroxide. Iraqi Journal of Science, 2168-2172.

[30] Koumbi L (2017). Dietary factors can protect against liver cancer development. World journal of hepatology 9, 119. https://doi.org/10.4254/wjh.v9.i3.119.

[31] Krinke GJ (2000). The laboratory rat: Elsevier.

[32] Kshirsagar A, Ingawale D, Ashok P, Vyawahare N (2009). Silymarin: A comprehensive review. Pharmacognosy Reviews 3 , 126.

[33] Liu Y, Zheng D, Su L, Wang Q, Li Y (2018). Protective effect of polysaccharide from Agaricus bisporus in Tibet area of China against tetrachlorideinduced acute liver injury in mice. International journal of biological macromolecules 118, 1488-1493. https://doi.org/10.1016/j.ijbiomac.2018.06.179.

[34] Lopes-Virella MF, Stone P, Ellis S, Colwell JA (1977). Cholesterol determination in high-density lipoproteins separated by three different methods. Clinical chemistry 23, 882-884. https://doi.org/10.1093/clinchem/23.5.882.

[35] Nieminen P, Kärjä V, Mustonen A-M (2009). Myo-and hepatotoxic effects of cultivated mushrooms in mice. Food and Chemical Toxicology 47, 70-74. https://doi.org/10.1016/j.fct.2008.10.009.

[36] Nishikimi M, Roa N, Yogi K (1972). Improved method for the determination of red blood cell superoxide activity Biochem. Biop. Res. Common 46, 849-854. https://doi.org/10.1016/S0006-291X(72)80218-3.

[37] Ohkawa H, Ohishi N, Yagi K (1979). Assay for lipid peroxides in animal tissues by thiobarbituric acid reaction. Analytical biochemistry 95, 351358. https://doi.org/10.1016/0003-2697(79)90738-3.

[38] Omar A, Abou-Alfa GK, Khairy A, Omar H (2013). Risk factors for developing hepatocellular carcinoma in Egypt. Chinese clinical oncology 2.

[39] Paglia DE, Valentine WN (1967). Studies on the quantitative and qualitative characterization of erythrocyte glutathione peroxidase. The Journal of laboratory and clinical medicine 70, 158-169.

[40] Pujar S, Kashinakunti S, Gurupadappa K, Manjula R (2011). Serum MDA, antioxidant vitamins and erythrocytic antioxidant enzymes in chronic alcoholic liver disease-a case control study. Al Ameen J Med Sci 4, 315-322.

[41] Reitman S, Frankel S (1957). Glutamic-pyruvate transaminase assay by colorimetric method. Am. J. Clin. Path 28, 56. https://doi.org/10.1093/ajcp/28.1.56.

[42] Richmond W (1973). Preparation and properties of a cholesterol oxidase from Nocardia sp. and its application to the enzymatic assay of total cholesterol in serum. Clinical chemistry 19, 1350-1356. https://doi.org/10.1093/clinchem/19.12.1350.

[43] Russmann S, Kullak-Ublick GA, Grattagliano I (2009). Current concepts of mechanisms in drug-induced hepatotoxicity. Current medicinal chemistry 16, 3041-3053. https://doi.org/10.2174/092986709788803097.

[44] Ruthes AC, Smiderle FR, Iacomini M (2015). D-Glucans from edible mushrooms: A review on the extraction, purification and chemical characterization approaches. Carbohydrate polymers 117, 753-761. https://doi.org/10.1016/j.carbpol.2014.10.051.

[45] Sacchetti L, Castaldo G, Fortunato G, Salvatore F (1988). Improved procedure for measuring gamma-glutamyltransferase isoenzymes in serum. Clinical chemistry 34, 419-422. https://doi.org/10.1093/clinchem/34.2.419.

[46] Shekhany KA, Al-Jibouri MH, Faraj MK (2012). The protective effect of white button mushroom (Agaricus bisporus) extract against zearalenone toxicity in albino mice. In: Proceedings of the 4th Kurdistan Conference on Biological Sciences. University of Duhok. p 10.

[47] Singhal KG, Gupta GD (2012). Hepatoprotective and antioxidant activity of methanolic extract of flowers of Nerium oleander against CCl4-induced liver injury in rats. Asian Pacific Journal of Tropical Medicine 5, 677-685. https://doi.org/10.1016/S1995-7645(12)60106-0

[48] Soares AA, de Oliveira AL, Sá-Nakanishi AB, Comar JF, Rampazzo AP, Vicentini FA, Natali MR, Gomes da Costa SM, Bracht A, Peralta RM (2013). Effects of an Agaricus blazei aqueous extract pretreatment on paracetamol-induced brain and liver injury in rats. BioMed research international 2013. https://doi.org/10.1155/2013/469180.

[49] Teplyakova TV, Psurtseva NV, Kosogova TA, Mazurkova NA, Khanin VA, Vlasenko VA (2012). Antiviral activity of polyporoid mushrooms (higher Basidiomycetes) from Altai Mountains (Russia). International Journal of Medicinal Mushrooms 14. https://doi.org/10.1615/IntJMedMushr.v14.i1.40.

[50] Vargas-Mendoza N, Madrigal-Santillán E, Morales-González Á, Esquivel-Soto J, Esquivel-Chirino C, y González-Rubio MG-L, Gayosso-de-Lucio JA, Morales-González JA (2014). Hepatoprotective effect of silymarin. World journal of hepatology 6, 144. https://doi.org/10.4254/wjh.v6.i3.144.

[51] Walter M, Gerade H (1970). A colorimetric method for determination bilirubin in serum and plasma. Micro Chem J 15, 231-236. https://doi.org/10.1016/0026-265X(70)90045-7.

[52] Wang H, Ng T (2006). Ganodermin, an antifungal protein from fruiting bodies of the medicinal mushroom Ganoderma lucidum. Peptides $27,27-30$. https://doi.org/10.1016/j.peptides.2005.06.009.

[53] Wieland H, Seidel D (1983). A simple specific method for precipitation of low-density lipoproteins. Journal of Lipid Research 24, 904-909.

[54] Wilson PW, Abbott RD, Garrison RJ, Castelli WP (1981). Estimation of very-low-density lipoprotein cholesterol from data on triglyceride concentration in plasma. Clinical chemistry 27, 2008-2010. https://doi.org/10.1093/clinchem/27.12.2008. 